\title{
The impact of organisational culture on attitudes concerning change in post-soviet organisations ${ }^{*}$
}

\author{
Ruth Alas, Maaja Vadi ${ }^{* *}$
}

906 employees from Estonian companies were studied in order to explore how task-orientation and relationship-orientation of organisational culture influence attitudes to the process of organisational change among employees in post-socialist organisations. The current survey indicates that people who began working in the former Soviet Union differ from those who started their careers during the subsequent transition period according to the way they form their attitudes toward change. Relationship-orientation of organisational culture predicts a belief in the benefits of change only in the group of people who started their work life in Soviet organisations.

In einer Studie wurden 906 estnische Mitarbeiter von Firmen studiert um zu untersuchen, wie die Aufgabenorientierung und Beziehungsorientierung in der Organisationskultur die Einstellungen von Angestellten zum Prozess von organisatorischen Veränderungen in post-sozialistischen Organisationen beeinflusst. Die neueste Studie zeigt einen Unterschied hinsichtlich der Einstellung zu Veränderungen zwischen jenen die in der früheren Sowjetunion $z u$ arbeiten begannen und jenen die ihre Karriere in den darauf folgenden Jahren des Übergangs starteten. Die Beziehungsorientierung in einer Organisationskultur sagt nur einen Glauben an Vorteile von Veränderungen in der Gruppe von Menschen voraus, die ihr Arbeitsleben in sowjetischen Organisationen begannen.

Key Words: Organizational change / organizational culture / employees' attitudes toward changes / post-soviet organization

\footnotetext{
${ }^{*}$ Manuscript received: 19.9.02, revised: 10.2.03, accepted: 26.02 .03

** Ruth Alas, born 1960, acting Head of Chair of Management, Estonian Business School. Research areas: Factors influencing implementation of organizational changes and organizational learning in post-soviet organizations. Corresponding address: Ruth.Alas@ebs.ee

Maaja Vadi, born 1955, professor, Tartu University. Research areas: Organizational culture, Values, Collectivism. Corresponding address: MVadi@mtk.ut.ee
} 


\section{Introduction}

The keywords concerning today's economy include changing environment and divergent work force. Estonian organisations have operated in a turbulent environment for more than 10 years. The heritage of 50 years of Soviet occupation has left Estonia with a divergent workforce with differing attitudes toward change in society and in organisations. People have started their careers and formed their work-related attitudes in different economic systems - some during a planned economy and some during the recent economic reforms. According to social scientists, strong attitudes may be resistant to change because people are motivated to defend their attitudes and a person's current attitudes function to shape the formation of new attitudes (Brief 1998).

Research in transition countries has shown that the transfer of knowledge from market-economy practices often fails because of institutional and cultural tensions and conflict (Clark and Geppert 2002). According to Edwards and Lawrence (2000) the emergent change to processes in transition countries can only be truly understood by examining the constitutive practices of individuals and groups at the local micro levels of the economic system.

In this paper the transition from a centrally planned economy to a market economy is viewed from a socio-economic perspective, focusing particularly on the influence of organisational culture on attitudes toward change. Research and theory development regarding the social aspects of organisational change in transforming countries with rapidly changing environments has been undertaken by Breu (2001), Child and Czegledy (1996), Clark and Soulsby (1999), Liuhto (1999a, 1999b), Soulsby (2001), Thomson (2001), Weik (2001) and others, who turned most of their attention upon managers. At the same time research in post-soviet enterprises indicates more problems with attitudes to change among workers and lower level managers than top managers (Clarke et al. 1994). The research question here is concerned with how different environments have influenced the way people form their attitudes toward change in organisations. In this exploratory study we compare how organisational culture helps to increase employee commitment to organisational change in groups of lower level employees with a different work experience. In order to assess employee attitudes the authors developed a measure.

As problems concerning groups with different work histories and attitudes are common to several post-socialist countries (Dobosz and Jankowicz 2002: 357) current research is important not only for Estonia, but also for other countries facing similar circumstances.

In this paper a brief overview of the role of organisational culture in the organisational change process will be followed by the results of empirical research in selected Estonian companies. 


\section{Organisational change}

Based on research in the Czech Republic, Clark/Soulsby (1999) concluded that the transition from socialism to a market economy is simultaneously a radical change at all levels of society (from the macro to the individual), which has been characterised by a high level of uncertainty and ambiguity. The changes in post-soviet organisations have been deeper than those typical of a market economy because the new economic order is based on different attitudes and values and attempts to shift the organisational culture toward new values or beliefs, and this has been considered one of greatest challenges (Bluedon 2000). It has been much easier to transfer technology and change structures than to change culturally embedded practices in transition countries (Clark/Geppert 2002).

Alas/Sharifi (2002) studied 137 Estonian companies and found what 90\% had made transformational changes and $61 \%$ had changed their organisational culture. Liuhto (1999a) discovered differences between the behaviour of Estonian managers during the implementation of changes compared to managers in established capitalist countries. By studying the environmentorganisation relationship in Estonia he concluded that strategies for change and types of changes differ in stable and unstable environments. In countries with an established market economy, managers in more uncertain environments attempt to anticipate events and act in a more proactive way than their colleagues in more stable conditions. In Estonian organisations Liuhto got the opposite result: in the earlier turbulent environment managers acted more reactively and when the situation started to stabilise in 1995, management of change started to be more proactive. This indicates that Estonian organisations constitute an appropriate laboratory for studying change.

The implementation of organisational change has been considered a step-bystep process in academic literature. If we compare later models to the first model developed by Lewin (1951), authors (Beer et al. 1990; Kotter 1998) have tended to pay more attention to the unfreezing stage. In order to reduce forces in favour of the status quo it is necessary to persuade people of the need for change (Lewin 1951). In the moving stage, forces in favour of change should be increased - attitudes, values and behaviours should be pushed to a new level (ibid). In order to achieve this move a change in people's mindsets is necessary (Sathe/Davidson 2000). This task was especially difficult in the stagnated Soviet Union. To manage such a difficult task people need to be interested in staying with a particular organisation-committed to their organisation.

\section{Employee attitudes in the organisational change process}

Employee attitudes are considered an indicator of the future success of an organisation (Hurst 1995). According to Cooper/Croyle (1984) a person's 
attitudes influence that person to act in a certain way instead of another. In the context of organisational change, attitudes to change - the benefits of the change and the competence of managers to implement these changes-become important. When seeking the information employees need for decision-making they focus on information consistent with their attitudes (Frey 1986).

Starting from the ceminal study by Coch and French (1948) theorists have considered participation as the best method for achieving employee commitment to change. Research results from post-soviet countries show somewhat different results: Polish employees decline invitations to participate in decision making, and, moreover, interpreted this as a sign of the management's loss of orientation (Piske 2002).

As change requires learning new skills, behaviours and attitudes, it demands a certain effort from employees. In order to use their energies for this purpose employees should be motivated to maintain their position and membership in a certain organisation. Two constructs, commitment and satisfaction have both been considered as indicators of whether individuals are effectively connected to an institution or might quit (Holton/Russell 1999; Meyer/Allen 1997; Randall et al. 1990). Commitment attitudes could lead to commitment behaviour, which would in turn influence commitment attitudes (Reichers 1985). If a person develops sufficient positive attitudes or a sense of goal congruence, it also indicates the person's level of commitment to change.

Several studies have shown job satisfaction as a contributor to and predictor of organisational commitment (Johnson/Jones-Johnson 1992; McNeeseSmith/Nazarey 2001). Commitment and satisfaction both have affective components. Job satisfaction, as defined by Locke (1976) is affective: a pleasurable emotional state resulting from appraisal of ones work. Affective commitment has been viewed as reflecting an affective orientation toward an organisation (Meyer/Allen 1997). Usually, in a rapidly changing environment, there is an insufficient amount of information for rational decision making, and so affective components play a significant role in evaluating the need for change. Unfortunately most of the scales for measuring job satisfaction are cognitively laden and do not assess the affective element. Also, the role of coworkers in the formation of attitudes has not been emphasised in assessments of job satisfaction. The social information-processing approach to job attitudes argues, that jobs can be interpreted in a multitude of ways and employees rely on social sources of information, and so cues from their co-workers contribute to the formation of job attitudes (Salanci/ Pfeffer 1978).

Although job satisfaction is one of the most widely researched topics in organisational psychology the findings are still contradictory (Meyer and Allen 1997:43-45) and vary across different social policies and economic environments in different countries (Judge et al. 2001). Also, the changing nature of work can affect the consequences of job satisfaction both in terms of 
the type and subsequent meaning of these consequences as well as the relationship between job satisfaction and other variables (Brief 1998). This makes it worthwhile investigating job satisfaction in Estonia.

Attitude strength depends on the extent to which these attitudes are related to each person's own deeply held philosophical and political values and are of concern to the person's social group (Boninger et al. 1995). This indicates the role of organisational culture in attitude formation.

\section{The role of organisational culture in shaping employee attitudes}

According to Lang/Steger (2002), problems East-European companies have in adopting Western practices stem from national and organisational cultures.

In the context of this survey the authors see organisational culture from a functional perspective as an adaptation mechanism, which helps an organisation to adapt and survive in a changing environment. This is consistent with the definition of organisational culture given by Schein (1992), that organisational culture is the pattern of basic assumptions that a given group has invented, discovered, or developed in learning to cope with its problems of external adaptation and integral integration. Trice/Beyer (1993) have also connected culture with environment, seeing organisational culture as a collective response to uncertainty and chaos.

Although the term commitment is not used in the definition of culture, part of the idea of sharing values and goals is being committed to them (Beyer et al. 2000). Several research results indicate a connection between employee attitudes and organisational culture. According to the research evidence, managers can increase employee satisfaction by creating cultures with characteristics expressed in terms of collegiality and collaboration (Xin Ma/MacMillan 1999). Meglino/Ravlin/Adkins (1989) indicated that organisational culture influences both the satisfaction and commitment of newcomers. The impact is mutual. On the one hand, employee satisfaction and commitment to the organisation, including during change, could be improved by developing an appropriate organisational culture. On the other hand, job satisfaction could influence organisational culture - satisfied employees are more likely to engage in organisational citizenship behaviours beyond the requirements entailed in job descriptions, and by helping each other reduce the workload and stress of others (Bettencourt et al. 2001).

According to Schein (1992), organisational culture is influenced by task- and relationship-orientation. Harrison (1995) distinguishes between task and person oriented organisational cultures. Task culture emphasises the superiority of the goals of the organisation over the member's personal goals. Person oriented orientation like Schein's relationship-orientation is based on warm and harmonious interpersonal relationships. These two orientations - task- 
orientation and relationship-orientation - are the vital aspects of organisational culture that can influence employee attitudes. Goffee/Jones (2000) separate sociability, similar to relationship-orientation and solidarity, similar to taskorientation.

In the context of organisational change, task-orientation could influence people's attitudes by establishing clear goals and developing values, which could help the achievement of these goals at all levels of the organisation. But achieving employee participation in the beginning is not enough; ensuring that the change process does not reverse and building more effective relationships with peers are also necessary (Landau 1998). Relationship-orientation could influence people's attitudes toward change through informal structures and communication (Salancik and Pfeffer 1978).

To summarise the theoretical framework for this study, researchers of culture tend to view cultures as stabilising forces within organisations and use the concept of culture to explain resistance to change. This, they say, arises from threats to traditional norms and ways of doing things (Senge 1997) or from threats to basic assumptions, personal values, sources of security, and to friendship relationships (Miner 1978). To overcome resistance to change, Kotter and Heskett (1992) suggest increasing the adaptability of the organisation through developing an organisational culture based on values important for achieving a readiness for change.

Therefore, we propose that orientations of organisational culture may have different impacts on employee attitudes. In the current study, we have focused upon the way task-orientation and relationship-orientation in organisational culture influence employee attitudes about change.

\section{The empirical study of attitudes and organisational culture}

There are two main objectives in the current study. First, we explore how organisational culture and attitudes toward change are manifested in Estonian organisations.

The culture of organisations in the Soviet Union was found to be bureaucratic (Andréen et al. 1993: 178-179; Loogma 1988). Nurmi and Üksvärav (1994: 54) compared organisational cultures in Estonia and Finland based on Trompenaar's model and found that organisational culture in Estonian organisations was Eiffel tower type. This emphasis on hierarchy makes this type of culture suited to a stable environment, but too bureaucratic for the dynamic and highly competitive environment Estonia has today.

During the soviet period enterprises were internally passive due to the fact that the enterprises were overstaffed and work places were over-secured. The transformation away from central planning increased endogenous activity substantially, as the transition has both forced employees to be more active and 
at the same time created more favourable conditions for employee selfrealisation (Liuhto 1999b: 16).

In the second half of the 1980's enterprises were gradually given more autonomy in the Soviet Union and it was legal to establish enterprises, which operated outside the central planning. These enterprises could be owned by private citizens and joint ventures with foreign ownership. Radical reforms in Estonia started in 1987-88 when a group of theoreticians and practitioners debated the idea of economic autonomy for Estonia. In 1990 an important change occurred in the strategic aim of the reforms in Estonia: economic autonomy was replaced by independent statehood and the restoration of a market economy (Taaler 1995). According to opinions held by managers, stability started to increase by 1995 (Liuhto 1999a).

As conditions were so different, we have turned our attention to the influence this culture has had on employee attitudes. For this purpose employees are compared on the basis of having had work experience from the Soviet era or not. The experiences people have had influence their understandings and interpretations of realities (Weick 1979). During the totalitarian regime in the Soviet Union it was not safe to speak openly or share personal thoughts (Taagepera 1993). So, employees with work experience from the Soviet era have been used to getting interpretations of events from colleagues (Üksvärav, 2001). This habit may influence their understanding of change in organisations today. They have more to unlearn than younger people who started their careers in market oriented organisations.

Therefore we hypothesise, that relationship-orientation of organisational culture influences the attitudes toward change in people with a Soviet work experience more than those same attitudes in younger people without this experience.

Secondly, we aimed to develop a tool for measuring employee attitudes during the organisational change process. Currently there is no measure connecting assessments of the need for change, satisfaction with information about change, satisfaction with the competence of leaders and with the job itself and commitment to the organisation.

\section{The sample}

In order to find connections between employee attitudes in the process of organisational change and organisational culture, the authors conducted an empirical study of Estonian companies in 2000-2001. The research was done in 38 Estonian organisations with 906 respondents. The reports from the managers of these organisations indicated that in $90 \%$ of these organisations transformational changes had taken place and in the remaining organisations transactional factors had changed. This indicated that all the organisations 
studied had implemented change and were the right kind of target group for an investigation of attitudes toward change.

The companies were selected in a non-random manner, as the organisation registers do not have a solid basis for random sampling because only a fraction of the registered enterprises are active in Estonia. The aim was to get a sample structure similar to the economic structure in Estonia. As only $38 \%$ of the 100 companies selected agreed to participate in the survey, we did not get a structure exactly comparable with reality, but still, a variety of industries were represented in the study: $20 \%$ of respondents were from sales organisations, $11 \%$ from the production sector, $23 \%$ from transportation, $7 \%$ from telecommunications and $8 \%$ from banking. Respondents from the public sector amounted to $15 \%$. Some companies refused to participate because of the time it takes or just did not find it beneficial. Bigger companies with foreign ownership refused because of the large number of surveys already conducted in the organisation. There were also companies who did not explain the reasoning behind their refusal.

In Estonia the shift from state-determined enterprise activity to privately driven entrepreneurship was caused rather by the foundation of new private enterprises than by the privatisation of state enterprises. Only seven per cent of all private enterprises were created directly as a result of privatisation (Purju 1998). From our sample the largest part, $61 \%$ of enterprises, were formed in the most turbulent years between 1987 and 1994. Those organisations established before economic reforms started in Estonia, before the year 1987, amount to $17 \%$ of the sample of the current survey. The remaining $21 \%$ are even younger, having been established also in a more stable environment.

As the majority of organisations in Estonia are very small, a lot of small companies participated in the study. Only $40 \%$ of the companies in this sample employed more than 100 employees, $18 \%$ between 50 and 100, 13\% from 25 to 49 and $29 \%$ even less.

Using their age, the respondents are divided into three groups based on the extent of their work experience during the Soviet regime, which might have influenced their work-related attitudes. The oldest group $(n=423)$, people older than 35 years, started their working life and formed their work-related attitudes in the Soviet system. The middle group $(\mathrm{n}=298)$, people aged between 26 and 35, started their work life in the 1980's. This group might have had some work experience from Soviet times. But taking into consideration that the second half of the 1980's marked the beginning of economic transition and the movement toward an unknown economic stage for Estonian people, this group would have also been influenced by this atmosphere. This, in turn may have affected the formation of work-related attitudes so they could well have different attitudes to the older group. The younger group $(n=181)$, people 
younger than 26 years, entered the work force in the 1990's and have not had any work experience from Soviet times.

\section{Method}

The development of items for the Questionnaire for Measuring Employee Attitudes in the Process of Organisational Change (QEA).

The QEA was developed on the basis of items taken from widely used satisfaction and commitment scales. The 27 items concerned a wide range of different topics related to employee attitudes such as - (a) attitudes toward the organisation (e.g. "How much are your future plans connected with this organisation?"), (b) general attitudes toward the work itself (e.g."How satisfied are you with your present work in this organisation?"), (c) attitudes toward managers (e.g."Do you trust the management and think that their decisions are the best for the organisation?"), (d) the benefits of the current change (e.g." In your opinion, how necessary are the changes in the organisation?"), (e) information about the current change (e.g."Do you have enough information about the reasons, content and objectives of the changes?").

The survey used the Likert scale so the respondents could show their attitudes by choosing answers that range from strongly disagree (1) to strongly agree (5). The items were first prepared in Estonian and then translated into Russian by two independent translators.

\section{The Questionnaire for Measuring Organisational Culture (QOC)}

The QOC (Vadi et al. 2002) was used in order to measure two orientations of organisational culture: task-orientation and relationship-orientation. In the process of developing this questionnaire the idea that organisational culture is shaped by two major factors (Harrison 1995; Schein 1992) - organisational task- and relationship-orientation - was followed. One of the scales reflects the under-standing and attitudes of members of the organisation toward organisational tasks and the other scale covers the theme of interpersonal relationships within organisations (Vadi et al. 2002). The task-orientation of organisational culture reflects the extent to which all members are willing to support the achievement of common goals. A certain degree of freedom, acknowledgement for good work and the occurrence of constant positive change inspires organisational members. It makes people think more about the needs and objectives of the organisation (ibid). The relationship-orientation of organisational culture indicates belonging-ness. People assist each other in work-related problems and discuss all the important topics with each other. People know how to communicate with each other and there is a strong feeling of unity in difficult situations (ibid). 
The questionnaire consists of 43 items, 16 of these form two scales. Respondents were asked to indicate their agreement with the item on a 10-point scale ranging from completely disagree (1) to completely agree (10).

Table 1. Items and factor loadings in the QEA.

Item

Do you have enough information about the reasons, content and objectives of the changes?

Were you informed about the changes before their initiation?

Have the general objectives and development plans of your organisation been explained?

How much are you included in the implementation of the changes?

How actively does your management solve company problems?

How satisfied are you with the top managers of you company?

Do you trust the management and think that the decisions are the best for the organisation?

Does your superior manage to organise the work of subordinates well?

How satisfied are you with your present work in this organisation?

How satisfied are you with your present position in this organisation?

Do you usually come to work with pleasure?

How much are your future plans connected with this organisation?

How necessary in your opinion are the changes the organisation?

Do you believe that the planned reforms influence .15 the performance of the organisation positively?

Will your work conditions be improved after the changes?

Factor 1

.83

.82

.75

.71

.19

.17

.15

.06

.11

.21

.04

.13

.13

.15

.27

Note. $\mathrm{N}=906$. The items are an approximate translation from Estonian into English.
Factor 2 Factor 3 Factor 4 $\begin{array}{lll}.17 & .10 & .17\end{array}$

$\begin{array}{lll}.16 & .10 \quad .17\end{array}$

$.29 \quad .11 \quad .09$

$\begin{array}{lll}-.03 & .19 & .16\end{array}$

$\begin{array}{lll}.76 & .18 & .10\end{array}$

$\begin{array}{lll}.75 & .21 \quad .20\end{array}$

$\begin{array}{lll}.71 & .20 & .31\end{array}$

$.69 \quad .21 \quad-.01$

$.17 \quad .77 \quad .03$

$.14 \quad .76 \quad .03$

$.20 \quad .65 \quad .19$

$.23 \quad .63 \quad .15$

$\begin{array}{lll}.04 & .07 \quad .84\end{array}$

$.25 \quad .11 \quad .80$

$.14 \quad .20$

\section{Results}

\section{New Scales of Employee attitudes toward Change (QEA)}

A principal component analysis and factor analyses with varimax rotation was completed for the 27 items. In order to develop subscales for measuring attitudes, items were selected with a factor load in this particular factor above [ 0.30] and the same load in other factors below [ 0.30] (Table 1). The four factors received describe together $63.2 \%$ of initial variability. The internal 
consistency, or Cronbach's Alpha coefficient, is between .74 and .84 for all scales.

So, we developed a questionnaire for measuring employee attitudes during the implementation of organisational changes. The final version consists of 15 items, which form four subscales. The content of the scales in the light of statements, which have the highest factor loadings, was the following:

The four items of the first scale, satisfaction with information (SI) addressing whether employees were satisfied with the information they received, depended on employee involvement in the change process and how much information was given to employees about the current changes and company goals. Naturally, employees want this information before the changes are initiated, rather than after the fact.

The second scale from four items addresses satisfaction with the leadership (SL), the following issues were most important for employees: how actively does management solve company problems, can management and their decisions be trusted, and how well can superiors organise the work of subordinates.

Table 2. The manifestation of attitudes and organisational culture.

\begin{tabular}{|c|c|c|c|c|c|c|}
\hline & \multicolumn{4}{|c|}{ Attitude scales } & \multicolumn{2}{|c|}{ Scales of QOC } \\
\hline & $\mathrm{BC}$ & SI & SL & $\mathrm{CS}$ & TO & RO \\
\hline & M SD & M SD & M SD & M SD & $\mathrm{SD}$ & SD \\
\hline $\begin{array}{l}\text { The entire } \\
\text { sample } \\
(\mathrm{n}=906)\end{array}$ & 3.29 .84 & 2.76 .92 & 3.41 .72 & 3.51 .69 & 5.331 .49 & 5.971 .42 \\
\hline $\begin{array}{l}\text { Younger age } \\
\text { group }(\mathrm{n}=181)\end{array}$ & 3.37 .73 & 2.76 .90 & 3.44 .70 & 3.39 .69 & 5.521 .41 & 6.071 .38 \\
\hline $\begin{array}{l}\text { Middle age } \\
\text { group }(\mathrm{n}=298)\end{array}$ & 3.38 .83 & 2.94 .91 & 3.39 .74 & 3.53 .63 & 5.461 .48 & 6.111 .41 \\
\hline $\begin{array}{l}\text { Older age group } \\
(\mathrm{n}=423)\end{array}$ & 3.19 .88 & 2.64 .93 & 3.41 .72 & 3.56 & $5.17 \quad 1.5$ & $\begin{array}{ll}5.84 & 1.4\end{array}$ \\
\hline
\end{tabular}

Note. BC - Benefits of change (1-5 point scale)

SI - Satisfaction with information (1-5 point scale)

SL - Satisfaction with leadership (1-5 point scale)

CS - Organisational commitment and job satisfaction (1-5 point scale)

TO - Task-orientation of organisational culture (1-10 point scale)

RO - Relationship-orientation of organisational culture (1-10 point scale)

The third scale connected organisational commitment and job satisfaction (CJ) by combining four questions about the willingness to continue working for a particular organisation and satisfaction with the present job. 
The fourth scale includes three questions about the benefits of change (BC) including how necessary the changes were for the organisation and how individuals benefit from these changes.

\section{Manifestation of attitudes and organisational culture}

We propose that organisational culture and attitudes toward the process of change vary between different groups within an organisation. Differences in attitudes and organisational culture according to the three age groups are shown in Table 2.

The one-way ANOVA LSD Post Hoc test was used to screen out statistically significant differences between age groups. Results in Table 3 indicate statistically significant differences in evaluations on five out of six scales - both scales of organisational culture and three of the scales of attitudes. According to evaluations of task- and relationship-orientation of organisational culture and the evaluation of the benefits of change the two younger age groups were similar, but both groups differed from the oldest age group. The oldest group had ranked all these scales lower than either of the younger groups (see Table $3)$.

Table 3. A comparison of attitudes and organisational culture between age groups according to the Post Hoc test.

\begin{tabular}{|l|c|c|c|c|c|c|c|c|c|c|c|c|}
\hline & \multicolumn{2}{|c|}{ BC } & \multicolumn{2}{c|}{ SI } & \multicolumn{2}{c|}{ SL } & \multicolumn{2}{c|}{ CS } & \multicolumn{2}{c|}{ TO } & \multicolumn{2}{c|}{ RO } \\
\hline & Dif. & $\mathrm{p}$ & Dif. & $\mathrm{p}$ & Dif & $\mathrm{p}$ & Dif. & $\mathrm{p}$ & Dif. & $\mathrm{p}$ & Dif & $\mathrm{p}$ \\
. & & & & & & & & & & & & \\
\hline $\begin{array}{l}\text { Younge } \\
\text { r- } \\
\text { Middle }\end{array}$ & -.02 & .756 & $-.31^{*}$ & .041 & .05 & .463 & $-.14^{*}$ & .030 & .06 & .690 & -.04 & .753 \\
\hline $\begin{array}{l}\text { Younge } \\
\text { r-Older }\end{array}$ & $.16^{*}$ & .025 & .12 & .158 & .02 & .715 & $-.17^{*}$ & .025 & $.35^{*}$ & .007 & .23 & .071 \\
\hline $\begin{array}{l}\text { Middle } \\
- \text { Older }\end{array}$ & $.19^{*}$ & .003 & $.29 *$ & .000 & -.03 & .626 & -.02 & .651 & $.30^{*}$ & .008 & $.27 *$ & .012 \\
\hline
\end{tabular}

Notes. Dif. - means difference between group

* - Statistically significant difference, $\mathrm{p}<.05$

Compared with the youngest age group this scale was ranked higher by the middle and the older age groups. Differences between the two older groups were not statistically significant while the commitment and satisfaction of the youngest group was significantly lower.

There were no differences between the three groups in regard to their satisfaction with management. At the same time the group between 26 and 35 years felt better informed than the others. 
To conclude, young people without any significant work experience from Soviet times found change more necessary and were more task-oriented and more relationship-oriented than their older colleagues.

Table 4. Connections between attitudes and orientations of organisational culture in different groups (according to standardised regression coefficient Beta).

\begin{tabular}{|c|c|c|c|c|c|}
\hline & & $\mathrm{B}$ & Beta & $\mathrm{t}$ & Sig. \\
\hline \multicolumn{6}{|l|}{ Benefits of change } \\
\hline Younger age group $n=181$ & TO & .261 & .505 & 6.549 & $.000 *$ \\
\hline $\mathrm{R}^{2}=.253, \mathrm{~F}(2,179)=30.26, \mathrm{p}<.001$ & RO & -.007 & -.005 & -.066 & .947 \\
\hline Middle age group $n=298$ & TO & .237 & .420 & 6.262 & $.000 *$ \\
\hline $\mathrm{R}^{2}=.184, \mathrm{~F}(2,295)=33.20, \mathrm{p}<.001$ & $\mathrm{RO}$ & .008 & .014 & .206 & .837 \\
\hline Older age group $n=423$ & TO & .198 & .340 & 6.137 & $.000 *$ \\
\hline $\mathrm{R}^{2}=.204, \mathrm{~F}(2,420)=53.94, \mathrm{p}<.001$ & RO & .092 & .155 & 2.793 & $.005^{*}$ \\
\hline \multicolumn{6}{|l|}{ Satisfaction with information } \\
\hline Younger age group $n=181$ & TO & .164 & .256 & 3.347 & $.001 *$ \\
\hline $\mathrm{R}^{2}=.273, \mathrm{~F}(2,178)=33.44, \mathrm{p}<.001$ & RO & .221 & .337 & 4.411 & $.000 *$ \\
\hline Middle age group $n=298$ & TO & .198 & .320 & 4.778 & $.000^{*}$ \\
\hline $\mathrm{R}^{2}=.188, \mathrm{~F}(2,295)=34.22, \mathrm{p}<.001$ & RO & .101 & .156 & 2.334 & $.020^{*}$ \\
\hline Older age group $n=423$ & TO & .219 & .357 & 6.668 & $.000^{*}$ \\
\hline $\mathrm{R}^{2}=.25, \mathrm{~F}(2,422)=70.55, \mathrm{p}<.001$ & RO & .125 & .195 & 3.643 & $.000 *$ \\
\hline \multicolumn{6}{|l|}{ Satisfaction with leadership } \\
\hline Younger age group $n=181$ & TO & .244 & .489 & 6.775 & $\left..000\right|^{*}$ \\
\hline $\mathrm{R}^{2}=.348, \mathrm{~F}(2,179)=47.73, \mathrm{p}<.001$ & RO & .064 & .158 & 2.187 & $.030^{*}$ \\
\hline Middle age group $n=298$ & TO & .228 & .458 & 7.036 & $.000 *$ \\
\hline $\mathrm{R}^{2}=.231, \mathrm{~F}(2,295)=44.28, \mathrm{p}<.001$ & RO & .083 & .035 & .537 & .591 \\
\hline Older age group $n=423$ & $\mathrm{TO}$ & .184 & .384 & 7.332 & $.000^{*}$ \\
\hline $\mathrm{R}^{2}=.281, \mathrm{~F}(2,422)=82.45, \mathrm{p}<.001$ & $\mathrm{RO}$ & .093 & .199 & 3.796 & $.000^{*}$ \\
\hline \multicolumn{6}{|l|}{$\begin{array}{l}\text { Organisational commitment and } \\
\text { job satisfaction }\end{array}$} \\
\hline Younger age group $n=181$ & $\mathrm{TO}$ & .140 & .285 & 3.577 & $.000 *$ \\
\hline $\mathrm{R}^{2}=.206, \mathrm{~F}(2,179)=23.19, \mathrm{p}<.001$ & RO & .116 & .230 & 2.896 & $.004^{*}$ \\
\hline Middle age group $n=298$ & TO & .150 & .355 & 5.152 & $.000 *$ \\
\hline $\mathrm{R}^{2}=.140, \mathrm{~F}(2,295)=23.99, \mathrm{p}<.001$ & RO & .013 & .030 & .437 & .662 \\
\hline Older age group $n=423$ & $\mathrm{TO}$ & .159 & .327 & 6.250 & $.000^{*}$ \\
\hline $\mathrm{R}^{2}=.283 \mathrm{~F}(2,422)=83.35, \mathrm{p}<.001$ & RO & .134 & .264 & 5.057 & $.000^{*}$ \\
\hline
\end{tabular}

Note. ${ }^{*}$ - coefficient statistically significant, $\mathrm{p}<.05$

TO - Task-orientation of organisational culture

RO - Relationship-orientation of organisational culture 


\section{Connections between organisational culture and attitudes}

Different groups may have a different understanding and perspective concerning the process of change. Our main purpose was to evaluate the influence of two scales of organisational culture on the variability of our four attitude scales. The authors analysed the relationships between the scales of attitudes and organisational culture by using the linear regression analysis.

In the analyses attitudes were taken as a dependent and two scales of orientations of organisational culture as independent variables. We calculated a standardised regression coefficient Beta (ß), which enabled us to predict how strongly orientations of organisational culture forecast attitudes toward change. Analysis was applied separately for all three age groups and every dependent variable.

According to the linear regression analysis results in Table 4, task-orientation of organisational culture (TO) predicts all four attitudes in all age groups studied. The predictive power of the other dependent variable relationship-orientation (RO) is not so uniform and differs between age groups for our attitudes scales. The determinant coefficients $\mathrm{R}^{2}$ are calculated for the regression model including both scales of orientations of organisational culture as independent variables. For example almost $25 \%$ of the variability in the perceived benefits of change in the younger age group can be explained by reference to task- and relationship-orientation of organisational culture: $\mathrm{R}^{2}=.253, \mathrm{~F}(2,179)=30.26, \mathrm{p}<$ .001 .

Relationship-orientation of organisational culture predicts all four attitudes only in the oldest group with soviet work experience.

The middle group, from 26 to 35 years, was least influenced by relationshiporientation of organisational culture. Relationship-orientation only predicted satisfaction with information in this age group. Attitudes toward leadership, the company and the work itself in this age group were only predicted by taskorientation of organisational culture.

The biggest difference was found concerning the scale indicating the benefits of change. Attitudes to the benefits of change in the two younger groups, respondents without any significant work experience from the Soviet Union, were not significantly influenced by relationship-orientation of organisational culture. Thus, our hypothesis is supported by the results of empirical analysis.

\section{Discussion and conclusions}

The results of this study contribute to understanding the influence of organisational culture on attitudes toward change in post-soviet organisations. We compared people with work experience from Soviet organisations to those who started their careers during transition. 
First, we found that organisational culture predicts attitudes in groups with different work experience in different ways. Attitudes toward the benefits of change depend on task-orientation of organisational culture in all groups regardless of previous work experience, but did not depend on relationshiporientation among people with any significant work experience from the Soviet Union. People older than 35 rely on relationships more than their younger colleagues. The most independent decision-makers belong to the group, who started their careers during the most turbulent period from the second half of the 1980's until 1995 - they need relationships only for getting information.

Second, the results of the current research indicate more favourable attitudes toward change and task-orientation of organisational culture among the younger employees, who already started their careers during economic reforms. The older members of organisations (those with soviet work experience) do not support organisational goals as much as younger members. This finding is consistent with a study in Poland, where an English manager complained about difficulties with changing people who are older and more "traditional" (Dobosz and Jankowicz 2002: 360). We understand that those people have some difficulties due to their previous experience. During the Soviet period companies had slack resources, because the state was responsible for guaranteeing work for everyone. Soviet organisations also acted as important social centres with cultural events and hobby circles (Nurmi/Üksvärav 1994), and organisational cultures promoted stability and people were not expected to differentiate from others. Avoiding failure was more important than achieving success. When the transition of Estonian society started, older people had a certain package of working habits and attitudes toward organisational tasks. However, this is somewhat different from the understanding of what organisations need nowadays. Today these relations have been replaced with relations based on competition and money (Üksvärav 2001). This may be considered as one reason why younger people, without habits obtained from planned economy, are less influenced by the opinions of others than older people.

It should be taken into consideration that during the planned economy people grew to maturity trusting that the state would take care of them and the current situation now causes confusion and fear among these people. During economic transition many of them found their profession obsolete or their professional skills not appropriate for producing quality goods. People's social and group identities crumbled or broke down and it became difficult for the individual to retain a reference structure on which to base rational action (Weik 2001). Unfortunately there are no theories in the Western world, which could help this whole generation to change their deeply rooted attitudes and to rebuild their social identity in their old age. 
From our findings we have developed some implications for managers of postsoviet organisations. As orientations of organisational culture predict employee attitudes toward changes, managers of post-soviet organisations should make cultural considerations part of the organisation's strategy and monitor the development of the organisational culture and periodically repeat a diagnosis of task- and relationship-orientations. Since attitudes toward such issues as leadership, information, the benefits of change and the employees' own commitment to job and company in every group depend on task-orientation of organisational culture; in order to achieve a more task-oriented culture the method used to create and communicate the vision for the organisation to every employee and also the method for discussing the employees' own perspectives in the company after the changes, start to be crucial for the successful implementation of change. There are different approaches needed for employees with different work experience. For those people who started their careers during the period of most fundamental changes (in the current survey this is age group from 26 to 35 ) information should be made available through various channels such as e-mail, Intranet, a web-page and so on. An atmosphere should also be created where differences between subordinates and superiors are not accentuated and authority should be delegated to lower levels in the organisation.

For the older generation with soviet work experience this probably would not work, because in the Soviet time people were more used to trusting the information they got through informal channels. For them informal communication networks should be used in order to promote beneficial values and goals and create the feeling of the necessity of the changes. To achieve this attitude change the message should be sent to the older group by people with whom older people could themselves identify. Managers could create a network of change agents in the organisation involving these older people. Managing the grapevine could be the main information tool in order to manage organisational changes successfully.

If the development of task-orientation could be enough to involve people without soviet work experience in the change process, then in order to ensure the commitment of those employees with soviet work experience, managers could develop relationship-orientation of organisational culture. Managers could preserve some practices that people valued in socialist organisations in the past in order to emphasise that the well being of people is important to management. There is positive evidence from such integration of old and new models in East-Germany, where managers took some features from the old model, such as attention to social needs and concerns and a strong sense of social responsibility in decision making (Brew 2001). Managers could also encourage people to get to know each other better by organising space and work in this way, that these people have the possibility to communicate more. Special time and space could be planned for coffee breaks; these people were used to 
these types of breaks in the Soviet period, but as these breaks were too long during the Soviet period, these employees themselves should regulate them.

Managers could also help those people with a Soviet heritage to develop a social identity and self-concept that fits the new environment. Training courses on self-development could help to address the issue of making the best use of personal resources. In order to encourage these people to shape their careers by themselves, courses on career development could be organised for introducing a voluntary concept of career (Rose 1989), which shows things from a different perspective to the one they have been used to. But before this, in order to get people to unlearn hold habits and to learn new skills, behaviours and also attitudes, managers first need to reduce uncertainty and stress and try to promote a feeling of trust. We suggest hiring a psychologist to conducts interviews in order to find out which fears cause resistance to change and learning, and what exactly these people are afraid of losing. Later people could be encouraged to use their own initiative through rewarding their good performance and by emphasising that people are not punished when they make mistakes.

To conclude, this study reveals that people who started their careers during the stagnation of the Soviet system developed attitudes toward changes differently to their younger colleagues who lack this experience. The importance of relationship-orientation of organisational culture in evaluating the benefits of change in the older age group indicates the need to manage networks of informal communication in post soviet organisations. Having special policies to deal with the grapevine could provide a competitive advantage for post-soviet organisations.

For future research the authors of this paper find the possibility of discovering how much this result is determined by features connected only with age particularly interesting. To this end a similar study could be conducted in a country without such an experience of a socialist regime.

\section{References}

Alas, R./Sharifi, S. (2002): Organizational Learning and Resistance to Change in Estonian Companies, Human Resource Development International, 5(3): 313-331.

Andréen, T./Härvén, F./Jansson, C./Kasimir, P./Lindahl, C./Rundquist, A.-L./Sjögren, A./Wallgren, C. (1993): A Case Study in seven Estonian Corporations. Transition studies, Vol. 1. Linköping University.

Beer, M./Eisenstat, R./Spector, B. (1990): Why Change Programs Don't Produce Change, Harvard Business Review, November-December:, pp 158-166.

Bettencourt, L.A./Gwinner, K.P./Meuter, M.L. (2001): A Comparison of Attitude, Personality, and Knowledge Predictors of Service-Oriented Organizational Citizenship Behaviors, Journal of Applied Psychology, 86(1), pp 29-41. 
Beyer, J.M./Hannah, D.R./Milton, L.P. (2000): Ties that bind: Culture and attachment in organizations, in: Ashkanasy, N.M./Wilderom, P.M./Peterson, M.F. (ed.): Handbook of Organizational Culture \& Climate, pp 323-338.

Bluedon, A.C. (2000): Time and Organizational Culture, in: Ashkanasy, N.M./Wilderom, P. M./Peterson, M.F. (Eds) Handbook of Organizational Culture \& Climate, 117-128.

Boninger, D.S./Krosnick, J.W./Berent, M. K. (1995): Origins of Attitude Importance: Selfinterest, Social Identification, and Value Relevance, Journal of Personality and Social Psychology, 68, pp 61-80.

Breu, K. (2001): The Role and Relevance of management Cultures in the Organizational Transformation, International Studies of Management \& Organization, 31(2), pp 2847.

Brief, A.P. (1998) Attitudes In and Around Organizations, Sage Publications.

Child, J./Czegledy, A. (1996): Managerial Learning in the Transformation of Eastern Europe: Some Key Issues, Organization Studies, 17(2), pp 167-79.

Clark, E./Geppert, M. (2002): Management Learning and Knowledge Transfer in Transforming Societies: Approaches, Issues and Future Directions, Human Resource Development International, 5(3): 263-277.

Clark, E./Soulsby, A. (1999): Organizational Change in Post-Communist Europe: Management and transformation in the Czech Republic, Routledge.

Clarke, S./Fairbrother, P./Borisov, V./Bizyukov, P. (1994): The Privatisation of Industrial Enterprises in Russia - Four case Studies, Europe-Asia Studies, 46(2), pp 179-241.

Coch, L./French, J.P. (1948): Overcoming Resistance to Change, Human Relation, 1: 512523.

Cooper, J./Croyle, R.T. (1984): Attitude and Attitude Change, Annual Review of Psychology, 35 , pp 394-426.

Dobosz, D./Jankowicz, A.D. (2002): Knowledge Transfer of the Western Concept of Quality, Human Resource Development International, 5(3), pp 353-367.

Edwards, V./Lawrence, P. (2000): Management in Eastern Europe, Basingstoke: Palgrave.

Frey, D. (1986): Recent Research on Selective Exposure to Information, in: Berkowitz, L. (ed.): Advances in Experimental Social Psychology, 19: 41-80. San Diego, CA: Academic Press.

Goffee, R./Jones, G. (2000): The Character of a Corporation: How your company's culture can make or break your business, Harper Collins Business.

Harrison, R. (1995): The Collected Papers of Roger Harrison, Jossey-Bass Publishers, San Francisco.

Holton, E.F./Russell, C.J. (1999): Organizational Entry and Exit: An Exploratory Longitudinal Examination of Early Careers, Human Performance, 12(3/4), pp 311-342.

Hurst, D. K. (1995): Crisis and Renewal: Meeting the Challenge of Organizational Change, Boston: Harvard Business School Press.

Johnson, W.R./Jones-Johnson, G. (1992): Differential Predictors of Union and Company Commitment: Parallel and Divergent Models, Psychology, 29: 1-12. 
Judge, T. A./Parker, S.H./Colbert, A.E./Heller, D./Ilies, R. (2001): Job Satisfaction: A CrossCultural Review, in: Anderson, N./Ones, D. S./Sinangil, H. K./Viswesvaran, C. (ed.): Handbook of Industrial, Work \& Organizational Psychology, Volume 2, Organizational Psychology, Sage Publications, pp 25-52.

Kotter, J.P. (1998): Leading Change: Why Transformation Efforts Fail, Harvard Business Review on Change. A Harvard Business Review Paperback, pp 1-21.

Kotter, J.P./Heskett, J. L. (1992): Corporate Culture and Performance, The Free Press.

Landau, J. (1998): Short-lived Innovation: Participation and Symmetrical Relationships in the Italian Public Sector', European Journal of Work and Organizational Psychology, 7(2), p 233.

Lang, R./Steger, T. (2002): The Odyssey of Management Knowledge to Transforming Societies: A Critical Review of a theoretical Alternative', Human Resource Development International, 5(3), pp 279-294.

Lewin, K. (1951): Field theory in social science, New York: Harper \& Row.

Liuhto, K. (1999a) The Impact of Environmental Stability on Strategic Planning - An Estonian Study, International Journal of Management, 16(1).

Liuhto, K. (1999b): The Organisational and Managerial Transformation in Turbulent Business Environments - Managers' views on the transition of their enterprise in some of the European former Soviet Respublics in the 1990's, Publications of the Turku School of Economics and Business Administration. Series A-9.

Locke, E.A. (1976): The Nature and Causes of Job Satisfaction, in: Dunnette, M.D. (Ed.) Handbook of Industrial and Organizational Psychology, Chicago: Rand McNally, pp 1297-1343.

Loogma, K. (1988) Organisatsiooni kultuur ja edukus, in: Elenurm, T./Preeks, I./Terk. E. (Eds): Organisatsiooni juhtimise ja majandamise edukus. Vabariikliku teadusliku konverentsi ettekannete teesid, Tallinn, pp 42-46.

McNeese-Smith, D.K./Nazarey, M. (2001): A Nursing Shortage: Building Organizational Commitment among Nurses/Practitioner Application, Journal of Healthcare Management, 46(3), pp 173-187.

Meglino, B. M./Ravlin, E.C./Adkins, C.L. (1989): A Work Values Approach to Corporate Culture: A Field Test of the Value Congruence process and its Relationship to Individual Outcome', Journal of Applied Psychology, 74, pp 424-432.

Meyer, J.P./Allen, N.J. (1997): Commitment in the Workplace: Theory, Research and Applications, Sage Publications.

Miner, J.B. (1978) The Management Process: Theory, Research, and Practice, Second edition. Macmillan Publishing.

Nurmi, R./Üksvärav, R. (1994): Estonia and Finland: Culture and Management, a Conceptual Presentation, Publications of the Turku School of Economics and Business Administration. Series A-9.

Piske, R. (2002): German Acquisitions in Poland: An Empirical Study on Integration Management and Integration Success, Human Resource Development International, 5(3), pp 295-312. 
Purju, A. (1998): Interrelationship between Privatization methods, Ownership Structure and economic Results - Evidences from Estonia, in: Proceedings of First International workshop on Transition and Enterprise Restructuring in Eastern Europe, 22-22 August, 1998, Copenhagen Business School, Copenhagen.

Randall, D./Fedor, D./Longenecker, C. (1990): The Behavioral Expression of Organizational Commitment, Journal of Vocational Behavior, 36, pp 210-224.

Reichers, A.E. (1985): A Review and Re-conceptualization of Organizational Commitment, Academy of Management Review, 12, pp 278-287.

Rose, N. (1989) Governing the Soul: The Shaping of the Private Self. London: Routledge.

Salancik, G.R./Pfeffer, J. (1978): A Social Information Processing Approach to Job Attitudes and Task Design, Administrative Science Quarterly, 23, pp 224-253.

Sathe, V./Davidson, E.J. (2000): Toward a New Conceptualization of Culture Change, in: Ashkanasy, N.M./Wilderom, P.M./Peterson, M.F. (ed.): Handbook of Organizational Culture \& Climate, pp 279-296.

Schein, E.H. (1992): Organizational Culture and Leadership, Jossey Bass Publishers.

Senge, P.M. (1997): The Fifth Discipline. The Art and Practice of the Learning Organization, Century Business.

Soulsby, A. (2001): The Construction of Czech Managers' Careers, International Studies of Management \& Organization, 31(2), pp 48-64.

Taagepera, R. (1993): Estonia - Return to Independence. Westview Press.

Taaler, J. (1995): Economic Reforms: The Main Stages, Programmes and Evaluations, in: Lugus, O./Hachey, G. A. (ed.): Transforming the Estonian Economy, Tallinn, pp 1-15.

Thomson, N. (2001): The Role of Slack in Transforming Organizations, International Studies of Management \& Organization, 31(2), pp 65-83.

Trice, H.M./Beyer, J.M. (1993): The Culture of Work Organizations, Prentice Hall.

Vadi, M./Allik, J./Realo, A. (2002): Collectivism and its Consequences for Organizational Culture. Working Paper Series. School of Economics and BA University of Tartu, $12 / 2002$.

Xin Ma/MacMillan, R.B. (1999): Influences of Workplace Conditions on Teachers' Job Satisfaction, Journal of Education Research, 93(1), pp 39-48.

Weick, K.E. (1979): The Social Psychology of Organizing, Reading MA: Addison-Wesley.

Weik, E. (2001): Myths in Transforming Process, International Studies of Management \& Organization, 31(2), pp 9-27.

Üksvärav, R. (2001): Management Culture in Estonia: Past and Present Features, in Suominen, A. (Ed.) Searching for the Boundaries of Business Culture, Publications of the Turku School of Economics and Business Administration. Series C-1, pp 103-120. 